FACTA UNIVERSITATIS

Series: Philosophy, Sociology, Psychology and History Vol. 19, N 2, 2020, pp. 73 - 91

https://doi.org/10.22190/FUPSPH2002073C

Original Scientific Paper

\title{
TELEVISION CULTURES OF SOCIALIST YUGOSLAVIA
}

\author{
UDC 316.774:654.197(497.1)
}

\author{
Antonija Čuvalo \\ University of Zagreb, Faculty of Political Science, Zagreb, Croatia
}

\begin{abstract}
The aim of the paper is to compare television cultures of Yugoslav republics during socialism. The paper is drawing on the recent comparative studies of socialist television in South and East Europe (Perško et al. 2021; Mihelj and Huxtable 2018; Imre 2016). Following the categories developed by Mihelj and Huxtable (2018) and Imre (2016), Yugoslav television cultures are here analysed in terms of a) generic composition and share of program modes, $b$ ) the level of transnationalism, $c$ ) the level of openness of television to social critique (semi-publicness), c) focus of television on private life (privatization), d) the gendering patterns, e) temporal orientation, $f$ ) characteristics of factual, humorous and history genres. Analysis is based on the data collected for the recently published book by Peruško, Vozab and Čuvalo (2021) and original content analysis of the JRT 79 Television Programme booklet, with a short description and basic info about the program that was shared within the JRT network. The result discerns differences between republic televisions (especially TV Ljubljana, TV Zagreb and TV Novi Sad) in program development toward neo-television, such as the differences in transnational orientation, temporal orientation, gendering patterns.
\end{abstract}

Key words: socialism, socialist television, television culture, Yugoslavia, genre, comparative research.

\section{INTRODUCTION}

During the last decade socialist television cultures gained more attention as a part of an increased interest in popular culture and ordinary, mundane aspects of "life under socialism" (Luthar and Pušnik 2010, 1). Several studies focusing on South and East Europe have been published during last decade covering television production, content and audiences during socialist times (e.g. Pušnik and Starc 2008; Reifova and Pavličkova 2013; Gumbert 2014; Peruško and Čuvalo 2014; Mihelj and Huxtable 2018, Peruško et. al. 2021).

Received October 9, 2020 / Accepted October 20, 2020

Corresponding author: Antonija Čuvalo

University of Zagreb, Faculty of Political Science, Lepušićeva 6, 10000 Zagreb, Croatia.

E-mail: antonija.cuvalo@fpzg.hr

(C) 2020 by University of Niš, Serbia | Creative Commons License: CC BY-NC-ND 
Interest in socialist television cultures represents a shift of the focus from systemic toward the more mundane, ordinary aspects of life under a socialist regime including popular culture (Luthar and Pušnik 2010, Gumbert 2014; Peruško et al. 2021). The underlying assumption here is that mundane practices reveal "the ways in which state power was exercised and negotiated at the level of personal experience and everyday life" (Luthar and Pušnik 2010, 1). Socialist popular culture comprises both, official and sanctioned mass culture (media production, media events, national festivals, etc.) on the one hand, and everyday cultural practice (reception of mass media, festive practices, fashion, youth culture, tourism, consumer culture etc.) on the other (Luthar and Pušnik 2010). While the system approach analyses institutional constraints and the interactions between different subsystems, mostly from the perspective of political science and history, the cultural approach to socialism is concerned with the ways how "individuals supported, reinforced or resisted and challenged the political system, and how they appropriated material culture to cope with conditions of everyday life" and "the ways how society understands and represents itself and how it is constructed through representation and gaze" (Luthar and Pušnik 2010, 1). Focus on culture and everyday life recognizes the individual agency and its capacity to challenge and negotiate structural pressures (Peruško et al. 2021; Peruško and Čuvalo 2014), enables avoiding of the simplified totalitarian perspective and sharp dichotomies between the official structures and everyday practices (Luthar and Pušnik 2010; Mihelj and Huxtable 2018). While the media system approach is focused on news media, media regulation and the position of the media system in relation to politics and the political system (Hallin and Mancini 2004) media cultures have been analysed in terms of their diverse genres and modes of communication, modes of production, audience engagement and their integration into globalized flows (Mihelj and Huxtable 2018; Gumbert 2014). The notion of media culture is here considered inseparable from the given media system (Peruško et al. 2021), while in the case of socialist Yugoslavia we can analyse relatively diverse republican media cultures and media systems within the shared political and social system. Television is the first mass medium established during socialism and its establishment went together with the establishment of a socialist consumer culture (Duda 2015, in Peruško et al. 2021). It is genuinely the main mass medium of socialist modernization (Gumbert 2014, Mihelj and Huxtable 2018; Peruško et al. 2021).

Together with the turn from the system approach to socialist media cultures, the dominant Cold War perspective on socialism has been abandoned in favour of the more diverse views on trajectories of media development around the world "resulting from multiple yet connected" modernities (Mihelj and Huxtable 2018, 3).

The period analysed in this paper refers to the time of paleo-television when television was "subject to censorship and considered ideal for its obedient and catholic audiences," and when there were "few things to see" (Eco 1983, 12). The majority of television genres could be divided into modes of fact and fiction. The logic of television was not yet fully developed and television genres and formats still did not include original television format and formulas. They were often merely transferred from already established media to television. Mass audiences could watch only a few channels (Missika 2006). During the period of paleo-television, RTV broadcasting on the European East was organized "in a very similar manner to Western European public service broadcasting with a public service mission, socialist style." (Peruško et al. 2021). 
Comparative research design within the media and communication research became recently well-established and advanced (Mihelj and Huxtable 2018) though single case studies of socialist television and television cultures remain dominant. Only a few studies apply comparative design to the analysis of socialist television cultures, like Sabina Mihelj and Simon Huxtable's (2018) comparative research on Polish, Soviet, Romanian, Yugoslav and East German television cultures published in the book From Media Systems to Media Cultures, and Aniko Imre's book Socialism. The recently published book of Zrinjka Peruško coauthored by Dina Vozab and Čuvalo (2021) included research on Yugoslav socialist media cultures as a part of a media system framework. The book tries to explain divergent trajectories of media systems in South East Europe by applying a longitudinal set-theoretical methodological approach.

This article presents some insights into the comparative analysis of the republican television program on SFRJ television published in program schedules for the year 1979 published in a book by Peruško, Vozab and Čuvalo (2021) and the original content analysis of JRT (Yugoslav Radio-Television) programme booklet for 1979. This year was chosen as a representative from the 1960s till the end of the most plural 1980s when media (radio, television and print) became mass media in terms of a large audience (Peruško et al. 2021).

Researchers who deal with the popular culture of socialist Yugoslavia face certain challenges: a) the culture, material life of socialist Yugoslavia and its artefacts are rapidly disappearing, some of them were destroyed in the wars of 1990s and early 2000s, some during the transition caused by the dissolving of socialist cultural institutions, some as a part of unresolved collective trauma which is manifested in the violence and destruction directed toward exterior sites and symbols of socialism, b) losing personal memories of life under socialism. Furthermore, when you go deeper into the life and institutions of the Socialist Federative Republic of Yugoslavia, you are facing its paradoxes (Županov 1983), internal diversities within and among republics, discrepancies between official culture (contained in documents and archives) and practiced culture (lost or partly saved in memories, socialist cultural production: books, movies, documentaries etc.). The diversity of official languages (Serbo-Croatian, Slovenian, and Macedonian) and two alphabets (Cyrillic, Latin) is another challenge for comparative studies of television cultures in Yugoslavia. And last, but not least and the least important, lack of internal and regional financial and/or human resources in academia and research institutions necessary for complex comparative research design.

\section{EUROPEAN SOCIALIST TELEVISION IN COMPARATIVE MEDIA RESEARCH}

The establishment of socialist television in eastern European countries paralleled the advent of the Cold War (Mihelj and Huxtable 2018, 1). Though there is a long history of the research of the growth and impact of television in Western countries within the media and communication field, the history and relevance of socialist TV remained marginal for the field. Recently, we can trace the increasing interest within the media and communication field in the socialist television cultures which is parallel with the reorientation of focus from media systems toward media cultures (Peruško et al. 2021, Mihelj and Huxtable 2018; Gumbert 2014; Imre 2016). This interest in socialist popular culture is parallel with the challenging approaches to the dominant Cold War framework for treatment of the socialist period. Socialism and its cultures were no more treated only as illegitimate, repressive (or 
totalitarian) but also as negotiated and/or resisted within the spheres of everyday life (Gumbert 2014).

Recent studies of socialist TV (Mihelj and Huxtable 2013; Imre 2016; Peruško and Čuvalo 2021) point to the shared trajectories of socialist and western televisions. The histories of socialist television "are both anchored in pre-socialist cultures and continue into post-socialism, never in isolation from the world of liberal capitalism" (Imre 2016, 1). The most liberal of socialist televisions, TV Ljubljana and TV Zagreb, established an official cooperation with the RAI (Italy) at the beginning of the 1960s. Ingrained in the context of the Cold War, socialist and Western televisions respond to each other by delivering their own vision of progress or by serving as a means of national integration and globalization (Mihelj and Huxtable 2018). Transnational orientation was inherent to both, socialist television and its Western rival. They both share a substantial portion of imported content (Mihelj and Huxtable 2018). They both respond to the needs of a fast growing urban population and their desire for light entertainment, and they both compete over the modern goal of "delivering good life to all" (Mihelj and Huxtable 2018, 9). Television was from its earliest days a collective and transnational process of cultural and technological innovation that occurred between East and West (Mihelj and Huxtable 2018; Vončina 1999). One of the greatest political risks of television broadcasting arises from the fact that broadcast signals cross state borders (Imre 2016; Vončina 1999).

Socialist state televisions were part of the communist propaganda apparatus and integral to the economic, political and cultural system devoted to the project of building a classless society under the leadership of the communist party (Mihelj and Huxtable 2018, 8 ). Though soon after its introduction television was used mostly for entertainment and relaxation. Socialist television thus served as a "gray zone" ${ }^{1}$ where official culture was simultaneously subverted and legitimized (Peruško et al. 2021) and which was partly free from strict political influence. European socialist systems tend to be more relaxed regarding popular culture and entertainment which were also less scrutinized. Consequently, within the cultural field some alternative interpretations and views and critical ideas were possible at least during more liberal periods under socialist rule (Peruško et al. 2021; Mihelj and Huxtable 2018; Zubak 2012; Žikić 2010; Senjković 2008). One source of the inherent crisis of socialism which had an impact on television were continual reforms along with economic problems (Imre 2016). Hungary, Poland, Czechoslovakia, and especially Yugoslavia, gradually allowed certain capitalist features like market orientation, and small private enterprises, international travels and competition on the global market (Imre 2016; see also Peruško et al. 2021).

Similar to its Western rival, socialist television made a great part of the texture of everyday life of people and was an important resource for ordering and understanding the world (Gumbert 2014). Gradual institutionalization of television as a domestic medium enabled the wide reach of the centrally produced messages in the comfort of people's private spaces (Mihelj and Huxtable 2018; see also Scannell 1995, 2013). The importance and the popularity of television media in the socialist media systems is at least partly the consequence of the fact that for its reach population it does not have to be massively

\footnotetext{
${ }^{1}$ An ongoing COST (European Cooperation in Science and Technology, https:// www.cost.eu) project "New exploratory phase in research in East European cultures of dissent," is investigating the gray cultural zones in socialism. See https://nep4dissent.eu/working-groups/group-2/
} 
literate. These countries tend to lag behind the West in terms of the literacy rate, similar to European Mediterranean countries (Peruško et al., 2021).

Though socialist television had an important role in "mediating the state's attempt to shape and discipline competing views of socialism", the specific historical context of the medium's development, its affordances and the context of consumption made this project inherently fragile. The live nature of television (Scannell 1995) held potential for wide "participation in revolutionary progress" (Mihelj and Huxtable 2018, 9). The wide range of television genres like propaganda films, live transmission of mass rallies, etc. offer possibilities for the engagement of audiences around revolutionary communist projects. What became clear from the beginning of socialist television was the need to "negotiate audience expectations and desires" (Gumbert 2014, 10) and even "stimulate public engagement and critique" (Mihelj and Huxtable 2018: 3).

Socialist television failed to fulfil its potential for the project of socialist modernisation of the ruling communist party due to inherent risks it does have for staging live appeal events with ordinary people, for the appeal of political speeches. Domestic reception of the centrally produced content restricted the power of the authorities to control the reception and diminish the potential of the media to promote mass mobilization (Mihelj and Huxable 2018, 10-11). While politicians did not manage to adapt to the new media, media professionals relatively soon were able realized the potential of the new medium. Gradually, communist authorities managed "to successfully "mobilize entertainment for political goals" (Mihelj and Huxtable 2018 , 12). The "communist ideology" became taken for granted as a part of the texture of everyday life", providing also the "basis for common reference points and shared experiences" (Mihelj and Huxtable 2018, 15).

Socialist television culture gained more attention recently, with the cultural turn in media and communication studies of socialism. During the last decade, several studies of television production, content and reception under socialism were published (Meyen and Scwer 2007; Pušnik and Starc 2008; Reifova and Pavličkova 2013; Gumbert 2014; Peruško and Čuvalo 2014; Mihelj and Huxtable 2018; Peruško et al. 2021). The focus is mostly on the institutional infrastructure, elite views, professional practices, TV programmes, and less on the audience practices and perspectives (Reifova and Pavličkova 2013; Luthar 2010). Though comparative research design became recently well-established and advanced within media and communication research, single case studies of socialist television and television cultures remain dominant (Mihelj and Huxtable 2018). We still do not know whether a certain individual country trends are shared across the region, and what are the patterns of shared trends? At the same time, it is hard to conclude on the sources of social impact of specific programmes when we do not know much about audience practices and reception (Mihelj and Huxtable 2018).

Only a few studies apply comparative design to the analysis of socialist television cultures, like Sabina Mihelj and Simon Huxtable's (2018) comparative research on Polish, Soviet, Romanian, Yugoslav and East German television cultures published in the book From Media Systems to Media Cultures, and Aniko Imre's book Socialism. The recently published book of Zrinjka Peruško coauthored by Dina Vozab and Antonija Čuvalo (2021) included research on Yugoslav socialist media cultures as a part of a media system framework. ${ }^{2}$

\footnotetext{
${ }^{2}$ The book tries to explain divergent trajectories of media systems in South East Europe by applying a longitudinal set-theoretical methodological approach.
} 


\section{THE CHARACTERISTICS OF EUROPEAN SOCIALIST TELEVISION CULTURES}

Comparative research on socialist television (Imre 2016; Mihelj and Huxtable 2018) shows complex and ambivalent interaction between television and the political system. Technically, the communist party owned or controlled the new media when television was (re)launched during the 1950s. But the medium had its own technological and programming logic (Scannel 1995, 2013). The lower cultural status of the medium allowed it to sometimes skip from the radar of the censors (Imre 2016). On the one hand, the socialist television was shaped by communist ideology and control over society, while on the other it was "a mix-andmatch of ideas imported and borrowed from Western European broadcasters", both resulting in contradictory goals and performances visible in the specificities of its genres (educational programmes, "cheerleading docufiction", entertainment, historical drama etc.) (Imre 2016, 8). Socialist television thus incorporates and mixes the communist project and its aesthetic with bourgeois legacy from the previous period (e.g. in television comedy) and from its Western rival. Another factor of disturbance, which was reflected also on television was caused by the gap between ideals and the actual and experienced socialist realities (Imre 2016). Early after its launching within the socialist context, television became a medium used primarily for entertainment and leisure (Mihelj and Huxtable 2018; Imre 2016; Gumbert 2016).

Anikó Imre's book TV Socialism (2016) explores aesthetic, political, and ideological dimensions of specific genres (reality-based educational programming, historical and adventure series, dramatic series, and comedic programs) on socialist televisions and their shifts since the end of the Cold War. The genres were selected based on their political and ideological roles. Imre in her study incorporated qualitative and quantitative research on socialist (and post-socialist) media industries and audiences, with archival sources and interviews with Hungarian television professionals and archivists. Her study reveals a complex and ambivalent medium, not an instrument of propaganda (Mihelj and Huxtable 2018; Imre 2016; Gumbert 2014).

Imre (2016) divided socialist television genres into four categories: 1) genres of realism and reality (educational programmes, public affairs, documentaries, quiz/game shows and reality crime programs), 2) genres of history (historical drama and adventure series), 3) genres of fiction (drama, soap operas) and 4) genres of humor (television comedy, satirical political humour).

Socialist genres of realism and reality share with Western European TV the ethos of public service and commitment to realism. They "both drew on the values of cultural nationalism and a top-down intention to educate and enlighten all social classes." (Imre 2016, 28). By the late 1960s and 1970s Soviet television changed the tone of realist TV from documentary realism to "emotional realism". This shift engenders the development of the concept of the "socialist way of life" (Imre 2016, 35). The concept signals a new direction of socialist ideology toward identifying unique moral, spiritual and emotional characteristics of life under socialism, superior to capitalism (genuine collectivism, comradeship, solidarity, moral health, the friendship among nations). The reason behind this was to move attention from failing economic competition with the West, and to find more effective television forms of citizens' emotional engagement. Emotional realism brought to the screen pictures of ordinary people "and their stories of everyday heroism" (Imre, 2016: 3) with a semi-religious tone (Mihelj and Huxtable 2018). Imre (2016) argues that in countries where the opposition to Soviet cultural colonization was most intense (Yugoslavia, Czechoslovakia, Poland, Hungary), dominant realist orientation was 
less sentimental and more ironic and sarcastic. Educational programmes covered not only school subjects (language, history, math, biology etc.) but also education in broader terms aimed at different categories of citizens (e.g. how to raise children, how to maintain good hygiene, how to cook, ski etc.), political education (Marxism, functioning of the socialist system), taste education (culture and art) and the provision of a public forum (for example the programme Current Debate by TV Belgrade 1965-1969). Educational and realist programmes incorporated also entertainment and play (programmes like TV guide, children's programmes)

Genres of history describe relationships toward history, memory, nostalgia. Fictional genres point to "the connections among gender, consumerism, and television." (Imre, 2016: 22). Special focus is given to the socialist soap opera and its representation of "superwomen, who can do it all with no reward other than pride" (Imre 2016, 22). Socialist television "incorporated and cultivated" a presocialist cabaret with inherent bourgeois entertainment into its genres of humour (Imre 2016, 22). In an analysed socialist TV satire, ironic sensibilities were combined with performative self-justifying forms. Some authors (Szecskő, in Imre 2016, 33) point to the fact that ideological control often dismissed fictional genres (except art) as entertainment which was considered as of lower value than realist TV genres, and as subject to market forces. Mihelj $(2013,2014)$ argues that comic television series and stand-up comedians represent the genre most often used as the conduit for a more direct social critique.

In their book, Sabina Mihelj and Simon Huxtable (2018) argue that socialist television cultures (Soviet Union, Poland, Romania, East Germany, Yugoslavia) differ on the a) character of gender relations, b) the level of acceptance of religious traditions, c) the nature of national historical narratives, d) foreign policies and transnational orientation, e) extents and form of party-state control over the media, and f) timing of infrastructural development and their relative core-periphery position. Their study shows how countries differ along seven dimensions (publicness, privacy, gendering, transnationalism, temporal orientation, and temporality $)^{3}$ :

a. Semi-publicness of socialist television. Publicness is defined in terms of the two promises of modern television, in terms of its public mission and in terms of television as a public sphere. Openness of television as a public sphere stems from the ability of television to bring public life under the scrutiny of audiences. Publicness of television in terms of its public mission refers to the provision of wide access to shared public goods (information, education, culture and entertainment). Authors found differences between the socialist televisions in openness to public critique, though criticism was allowed only if it did not challenge the legitimacy of communist rule;

b. Privatization of television refers to the extent to which television programme is focussed on private life and becomes adapted to the domestic context of reception by intimate modes of communication with audiences, by programmes dedicated to private life or through genres "designed to fit with the domestic rhythms" (Mihealj and Huxtable 2018, 35);

c. The gendering makes reference to the exposure of both sexes on the screens and the ways gendered structure of the audiences informed the production process, genre conventions and TV scheduling;

d. Temporal orientations concern the orientation of programme content to past, present or future, and the "modes and extents to which they engage" with the past, present and/or

\footnotetext{
${ }^{3}$ The dimensions secularization and extraordinary temporality were excluded due to lack of data.
} 
future. Mihelj and Huxtable's (2018) study reveals how socialist television was bound up with history and

e. The level of transnationalism is defined in terms of the openness to transnational exchange and influences and the origin of transnational links.

The insights from these two studies will be used for the comparison of the Yugoslav republican televisions in terms of their programme composition and their contribution to the shared public sphere.

\section{THE SOCIALIST TELEVISION SYSTEM OF YUgOSLAVIA}

Television in Yugoslavia was introduced relatively late compared to countries like France or the UK and at a similar time as other Mediterranean countries, Italy (1954), Spain and Portugal (1958), Greece (1966). Television began regular broadcasts first in the most developed republics, Croatia Slovenia and Serbia (1950s), followed by the other three republics, Bosnia and Herzegovina and Macedonia (1960s), and Montenegro (1970s). Two Serbian autonomous provinces, Vojvodina (northern Serbia) with a relatively high share of its Hungarian minority and Kosovo with its Albanian majority established regional televisions in 1975 (TV Novi Sad in Vojvodina and TV Priština in Kosovo). The context in which the television system in Yugoslavia was introduced and developed differed from both the Southern European countries and from the Eastern European socialist countries:

"The development of television went hand in hand with the establishment of the selfmanagement socialist system in Yugoslavia, which enabled a degree of market influence, freedom of speech, and pluralism" (Peruško et al. 2021, 1114).

Mihelj and Huxtable's (2018) research showed that Yugoslavia exhibited the most "liberal" type of socialism. Its relatively more diverse media culture was the product of a less centralized economy and openness to transnational cultural flows (see also Peruško and Čuvalo 2014). Western republics were further exposed to a wider selection of television programs delivered via trans-border signals from Austria and Italy, which was also the case for the neighbouring television signal regions within the country (Peruško et al. 2021).

From its beginning, the Yugoslav Radio and Television (Jugoslavenska radio televizija or JRT) was included in various working groups and managing bodies as a member of the European Broadcasting Union (EBU) (Peruško et al. 2012). Television professionals and journalists visited European and American media and regulators (e.g., the US Federal Communications Commission [FCC]). The television system was established through professional contacts with Western European companies such as the French Compagnie Française Thomson-Houston (CFTH) or the Italian Marelli, while certain institutions inherited liberal norms from previous periods, especially in Slovenia, Croatia, and Serbia (Peruško et al. 2021). The first television schedules were shaped by the practices of established Western television, which served as a role model for developing television in Yugoslavia (Vončina, 1999). During the Cold War, Yugoslavia took the position of nonalignment, and "clearly opted to be more connected to Western cultural flows and practices" (Peruško et al. 2021, 110; Mihelj and Huxtable 2018). Sabina Mihelj (2011) speculates that at least in some ways, Yugoslav televisions, particularly Slovenian, were more commercially oriented than some Western European public broadcasters. From the 1960s, media institutions had diverse sources of income: subscriptions for newspapers 
and license fees for radio and television broadcasting, sales to audiences, advertising, and state financing (Peruško et al. 2021). ${ }^{4}$

Television broadcasting was not institutionally centralized at the federal level, "and despite some centrally and politically driven trends toward unification, the republic radio and television systems remained institutionally independent and, therefore, diverse in terms of their technological equipment and financial and human resources" (Peruško et al. 2018). The federal umbrella organization, the JRT (established in 1954) was neither a television channel nor a broadcast organization, but rather an association of republic radio and television centres. The jurisdiction of the JRT was to coordinate the common program broadcasting, program exchange, and co-production. It was governed by a board of directors whose members were the general directors of the republic radio-television centres. The republic TV stations had significant autonomy in terms of their broadcasting policies and schedules. The exact distribution of shared versus domestic programs was not fixed and so varied across the republics over the decades:

"Due to differences between the republics with regard to their wealth, socio-demographic characteristics, and market conditions, the party leaders' orientation toward more liberal and pluralist or more centrist and unitary values, technological resources, and the professional skills and values of journalists and other media professionals, television audiences in different republics were not confronted with an identical TV culture" (Peruško et al. 2021, 115).

Croatia, Serbia, and Slovenia remained at the forefront of television development throughout the socialist period due to being the most technologically, professionally, and financially well-equipped TV centres (Peruško et al. 2021). At the same time, "the media and the public sphere in Bosnia and Herzegovina, Montenegro, and Macedonia were less open to dissent than those in the other three republics" (Peruško et al. 2021, 99). Due to the decentralization of the media, the public sphere was divided along republic lines, which led to a low degree of knowledge concerning other republics (Ramet 2002, 40, Kramberger et al. 2004; Obradović and Stupan 1968, in Peruško et al. 2021). The media were addressing mainly the public spheres of the particular republics, nurturing national identities rather than focusing on the official ideology of "Brotherhood and Unity" (Peruško et al. 2021, 103-4; see also Mihelj 2011). Television audiences preferred to receive news about their own republics and were less interested in developments in other parts of Yugoslavia (Obradović and Stupan 1968, in Peruško et al. 2021).

Compared to other media, television had the greater influence on the creation and maintenance of the common public sphere (Peruško et al. 2021; Vončina 1999). Shared television programs began at the end of 1958 following the establishment of the JRT (Vončina 1999). Daily news and informational programs were exclusively transmitted by TV Belgrade between 1959 and 1968. TV Zagreb, TV Ljubljana, and later other republic TV centers sent their material to Belgrade, where it was edited for inclusion in the common news program (Vončina 1999, 2001). Since 1968, daily evening news started to be broadcast from the various republics' studios while shared news was broadcast only on Sunday (Peruško et al. 2021; Vončina 1999, 2001). Thus, to some degree, inter-republic discussions were being

\footnotetext{
${ }^{4}$ Data regarding the broadcasting budget for 1971 show that government funding accounted only for $8 \%$ of the broadcasting budget, while license fees accounted for $73 \%$ and advertising for $19 \%$ (Robinson 1977). Due to the greater dependence of media organizations on advertising, media adopted profit orientation, and became oriented toward the entertainment content and specialized media products aimed at specific market niches (Mihelj 2011, see also in Peruško et al. 2021).
} 
achieved through TV news, which rotated between studios on some days of the week; nevertheless, due to language barriers and audiences oriented to more narrow republic issues, shared news was less popular.

During the 1970s, all the Yugoslav television services introduced a second channel, and color programming. The introduction of a second channel was followed by a significant increase in broadcasting time (Peruško and Čuvalo 2014; Peruško at al. 2021).

Soon after the introduction of television in Yugoslavia, television was perceived by its audience as a mainly entertainment form (51\% of all audiences in 1965) (Peruško et. al. 2021; Mihelj and Huxtable 2018; Mihelj 2013). The most popular programs among Croatian audiences were entertainment programmes (Peruško et al. 2021). The Croatian public was already familiar with Italian and Austrian television programmes, as well as with imported American entertainment series and soap operas (Vončina, 1999). The most popular television genres were light entertainment combining music with humor and fiction, especially comedy drama (Vončina 2003, 2005; Mihelj 2013, 2014; Mihelj and Huxtable 2018). Educational programs that combined entertainment with education and that were aimed at children gained cult status (Smogovci by TV Zagreb; Kocka, kocka, kockica by TV Belgrade; Nedjeljni zabavnik by TV Sarajevo). Audiences' preferences initially settled on quiz shows, film, entertainment, and drama programs (RTV Zagreb 1970).

\section{METHODOLOGY}

The following analysis combines two sources of data, a comparative study of television cultures published in the recently launched book coauthored by Zrinjka Peruško, Dina Vozab and Antonija Čuvalo (2021) Comparing Post-Socialist Media Systems The Case of Southeast Europe and original analysis of the JRT 79 Television Programmes booklet with a list, description and basic information (origin. authors, duration, number of episodes) of the tv programme from each republic that was a part of the shared JRT programme and was planned for broadcasting in all 6 republics. The booklet is divided into sections: education programme, programme for children, documentary, drama, music and entertainment. Each section contains a list of programme units from six republics and 2 autonomous provinces (Vojvodina and Kosovo).

The basis for the analysis is "genre" as a "transcultural form of expression" and a "a set of specific television genres", but with the consideration that "socialist genres do not exactly overlap with those derived from Anglo American television" (Imre 2016, 5). Genre provides a platform of recognition and comparison within Western television studies, television studies of socialism, and helps foreground the regional specificities of socialist tv.

The year 1979 was represented by one constructed week ( $\mathrm{K}=52$ days) featuring the following dates: June 27, March 20, May 11, June 2, August 23, October 14, and December 5. For 2016, we used one consecutive week (April 1-7). ${ }^{5}$ The analysed television schedules for 1979 were published in the main national daily newspapers (Delo, Nova Makedonija, Oslobođenje, Pobjeda, Večernji list, and Večernje novosti). As neither the newspaper archives nor the television schedules have been digitized into publicly available databases,

\footnotetext{
${ }^{5}$ Riffle et al. (1998, in Kripendorff 2004, 123) argue that "one constructed week adequately predicted the population mean," while Gerbner, Gross, Jackson-Beeck, Jeffries-Fox, and Signorelly (in Wimmer and Dominick 1994, 170) obtain comparable results from a consecutive week and a random yearly constructed week sample (Peruško and Cuvalo 2014; Peruško et al. 2021).
} 
library archives were consulted to obtain copies of the daily newspapers for 1979, which was considered representative of the socialist period. For 1979, we analysed all the nationwide terrestrial channels established within the country.

The unit of the content analysis was a television program as it was announced in the TV listings, with the assumption being that the listings reflect the actual reality of broadcast programs. This assumption is shared by other studies of the same type (Riffe 2008; Krippendorff 2004; Wimmer and Dominick 1994, in Peruško et al. 2021, see also Peruško and Čuvalo 2014). The analyzed tv channels were two channels from six Yugoslav republics: Bosnia and Herzegovina: TV Sarajevo 1, TV Sarajevo 2; Croatia: TV Zagreb 1, TV Zagreb 2; Macedonia: TV Skopje 1, TV Skopje 2; Montenegro: TV Titograd 1, TV Titograd 2; Serbia: TV Belgrade 1, TV Belgrade 2 and Slovenia: TV Ljubljana 1, TV Ljubljana 2.

Following the categories from Mihelj and Huxtable's (2018) and Imre (2016) studies, Yugoslav television cultures are here analysed in terms of a) generic composition and share of program modes, and b) the level of transnationalism. These two categories are analysed on the data collected for the recently published book Comparing Post-Socialist Media Systems The Case of Southeast Europe (Peruško et al. 2021). The sample covers the television program for 1979 as published in the main daily newspaper of each republic and represents one constructed week ( $\mathrm{K}=52$ days). Other five categories: a) publicness or openness of television to public critique, b) privatization (focus of television on private life), c) the gendering patterns, d) temporal orientation (past, present, future), and e) secularization, are analysed on the basis of the content analysis of JRT 79 Television programme booklet. Brief information on each TV program, published in the booklet was used for the interpretive analysis of the gendering patterns and of the characteristics of genres of reality, history, humor (Imre 2016).

\section{Comparative Study of Yugoslav TEleVision Cultures}

The content analysis of tv program schedules shows that Slovenia was ahead of other Yugoslav republics in terms of its program orientation. The reality genre, mostly cultural programs (including education) were the well-represented genre across all the television stations. Slovenia had the lowest share of informational programs (a composite category that included cultural and educational programs, current affairs, documentaries, and news). Furthermore, Slovenia had the most diverse program in terms of genres. Slovenia had the highest share of programs for children (16\%), films (11\%), and sports $(10 \%)$. This could be interpreted as an indication of the development of the more commercial and entertainment oriented "neo-television" in Slovenia, even in socialism (Eco 1983; Missika 2006, in Perško et al. 2021, 117). The category of entertainment includes sports, chat and talk shows, children's programs, media and popular culture, music (other than classical or jazz) together with quiz and game shows. All Yugoslav televisions together broadcasted $28 \%$ of entertainment program. The highest share of entertainment was on TV Ljubljana (38\%), followed by TV Skopje (28\%), TV Zagreb and TV Sarajevo (27\%), TV Titograd (24\%) and TV Belgrade (20\%).

Fiction (comedy, drama, film) was the least well-represented program group on Yugoslav television while TV Ljubljana (Slovenia) had the highest share of fiction programs (17\%), compared to other TV centres which broadcast between $8 \%$ and $10 \%$ of fiction. 
The relatively high share of informational programs on TV Belgrade (72\%) when compared to the other TV centres, especially Slovenia (45\%), might be interpreted as a lag in the television age but also at least partly this could be the consequence of the status of Belgrade as the federal political centre. Serbia was exhibiting the culture of the paleotelevision age in which information/news and education represented the main purposes of television (Eco 1983). The informational/factual formats (including news and current affairs, art and highbrow culture, and documentary) prevailed during prime time (19:3023:00) in all the republics, followed by the fiction genres (most prevalent in Slovenia [30\%], then Macedonia), while the others were around 20\%, and entertainment came in third (Slovenia, Macedonia, and Serbia in the lead with $18 \%$, with others between $13 \%$ and 15\%). During prime time (19:30-23:00), the diversity of the broadcast genres was lower than throughout the whole day, but with much higher shares of the entertainment and fiction genres (including genres of humour).

All the Yugoslav television stations were more adult oriented during prime time, while the morning and afternoon programs were oriented toward children and educational topics (reality genres).

The differences between the republics in the generic composition of prime-time programs and the orientation toward fiction or entertainment could be the result of differences in audience preferences but also of differences in financial, technological, and human resources between the republic TV centres. Some federal funds were distributed to the republics but the major source of income was from the licence fee and advertising (Peruško et al., 2012; Robinson, 1977). The less developed republics (Macedonia and Montenegro), with small markets, faced difficulties providing original programs, although their prime time was more oriented toward domestic programs than programs from other TV centres.

The most developed republics, Serbia (58\%), Croatia (48\%), and Slovenia (42\%) had the highest share of domestic production. The share of domestic programs was the smallest in Montenegro (7\%), which also had the highest share of TV programs from TV Belgrade (49\%). Bosnia and Herzegovina, Macedonia, and Montenegro had a lower share of domestic programs than of programs produced in Serbia. In Serbia, programs from other republics had relatively low shares. Exceptions were programs from Croatia $(17 \%)$ and Bosnia and Herzegovina (8\%). Programs from Serbia, Croatia, and Bosnia and Herzegovina were most frequently aired on Yugoslav republican televisions, probably due to the fact that their languages could be understood in all three republics. The Macedonian and Slovenian languages were not readily understood by other citizens, which might at least partly explain their smaller presence in the shared flow.

When we look at the production origins of the different genres broadcast across the SFRY, Serbian production dominates in all the genres (especially in light entertainment shows), except in relation to drama, films, and fiction for children, which were mostly produced in the EU. Republics with more developed and/or relatively bigger media markets (i.e., Serbia and Croatia) could muster more original programming. ${ }^{6}$ The genre diversity (all day minutes) was the highest in Slovenia and Bosnia and Herzegovina, while the prime-time genre diversity was the same in all six republics. The diversity of content with regard to the place of production was the highest in the smaller republics

\footnotetext{
${ }^{6}$ In 1968, TV Zagreb broadcast $29.9 \%$ of the JRT program, TV Belgrade $28.3 \%$, TV Ljubljana $24.3 \%$, TV Skopje 14.8\%, TV Sarajevo 2.5\%, and TV Titograd 0.2\% (YRT Yearbook 1971/1972, in Peruško et al. 2021).
} 
(Slovenia and Macedonia), while the larger republics relied more on their own programproducing capacities (Peruško et al. 2021).

The television culture was the most distinct in Slovenia, and it was also the most similar to the contemporaneous developments seen in the television genre composition in Western European countries), although it still lacked some genres already present on Western Europe television at that time (Peruško et al. 2021). The other five republics, especially Serbia, Croatia, Bosnia and Herzegovina and Montenegro, shared more of the television flow, and their television schedules had a more similar composition. The shared culture was mainly oriented toward school children through educational programming, while current affairs programs and the news were more nationally oriented. The afternoon program varied more from one republic to another.

Yugoslav television stations differed from the stations of the federation's socialist neighbours with regard to the international flow of television programs. While most socialist countries imported the majority of their programs from other socialist countries, on TV Belgrade during the early 1970s more than $80 \%$ of imported programs came from the West (Nordenstreng and Varis 1974, 25, in Peruško et al. 2021, 124). The majority of programs (45\% according to the YRT Yearbook 1971/1972) was from the United States (Peruško et al. 2021). Programs from the EU, the United States, and other countries had similar shares in most republic television systems.

The JRT booklet gives us more nuanced insight into the editorial policies and the contributions of republican television centres to shared Yugoslav culture as a part of the JRT (Yugoslav Radio-Television) though we cannot guarantee that the same program was actually broadcasted.

The JRT program booklet for 1979 contains a description of the 120 units of TV program from 6 republic televisions (TV Belgrade, TV Zagreb, TV Ljubljana, TV Sarajevo, TV Titograd and TV Skopje) and 2 TV televisions from autonomous provinces, Kosovo (TV Priština) and Vojvodina (TV Novi Sad). The highest share of programs in terms of program units and program minutes comes from TV Belgrade (29\% of program minutes, $20 \%$ of program units). Table 1 shows the contribution of each republic to the shared JRT program in minutes and in terms of the number of program units.

Table 1 Number of program units of JRT TV Program 1979 per republic and genre

\begin{tabular}{lccccccccr}
\hline & $\begin{array}{c}\text { TV } \\
\text { Belgrade Ljubljana }\end{array}$ & $\begin{array}{c}\text { TV } \\
\text { Novi Priština } \\
\text { Sad }\end{array}$ & $\begin{array}{c}\text { TV } \\
\text { Sarajevo }\end{array}$ & $\begin{array}{c}\text { TV } \\
\text { Skopje }\end{array}$ & $\begin{array}{c}\text { TV } \\
\text { Titograd }\end{array}$ & $\begin{array}{c}\text { TV } \\
\text { Zagreb }\end{array}$ & SFRY \\
\hline Children's Program & 2 & 4 & 2 & 3 & 1 & 0 & 2 & 0 & 14 \\
Documentary & 5 & 8 & 5 & 7 & 2 & 3 & 0 & 7 & 37 \\
Drama & $7,5^{*}$ & 4 & 1 & 4 & $6,5^{*}$ & 4 & 0 & 4 & 31 \\
Educational Program & 3 & 4 & 2 & 0 & 6 & 1 & 0 & 2 & 18 \\
Entertainment & 1 & 0 & 4 & 0 & 1 & 0 & 0 & 1 & 7 \\
Music & 5 & 0 & 2 & 2 & 1 & 2 & 0 & 1 & 13 \\
\hline Total & 23,5 & 20 & 16 & 16 & 17,5 & 10 & 2 & 15 & 120 \\
\hline \multicolumn{7}{c}{ are divided between TV Belgrade and TV Sarajevo } \\
\end{tabular}

The total duration of the program listed described in the booklet was 12937 minutes. The JRT 1979 Programme booklet was divided in 6 parts covering 6 program genre 
categories: Children's programs (1280 minutes, 14 program units), Educational programs (2841 minutes, 18 units), Documentary (2594 minutes, 37), Drama (4156 minutes, 31), Entertainment (224 minutes, 7 program units) and Music (1842 minutes, 13 program units) programs. These categories are defined by JRT.

Table 2 Program minutes in JRT TV Program 1979 per republics and genre

\begin{tabular}{|c|c|c|c|c|c|c|c|c|}
\hline & \multicolumn{2}{|c|}{ TV Belgrade } & \multicolumn{2}{|c|}{ TV Ljubljana } & TV Novi Sad & \multicolumn{2}{|c|}{ TV Priština } & \multirow{2}{*}{$\frac{\text { TV Sara }}{\mathrm{N}}$} \\
\hline & $\mathrm{N}$ & $\%$ & $\mathrm{~N}$ & $\%$ & $\mathrm{~N}$ & $\mathrm{~N}$ & $\%$ & \\
\hline Children's Program & 153 & $4 \%$ & 416 & $30 \%$ & 81 & 60 & $9 \%$ & 150 \\
\hline Documentary & 354 & $9 \%$ & 338 & $24 \%$ & 158 & 237 & $36 \%$ & 300 \\
\hline Drama & 1140 & $30 \%$ & 252 & $18 \%$ & 120 & 318 & $48 \%$ & 1124 \\
\hline Educational Program & 1015 & $27 \%$ & 401 & $29 \%$ & 49 & 0 & $0 \%$ & 1230 \\
\hline Entertainment & 60 & $2 \%$ & 0 & $0 \%$ & 104 & 0 & $0 \%$ & 30 \\
\hline Music & 1037 & $28 \%$ & 0 & $0 \%$ & 48 & 44 & $7 \%$ & 30 \\
\hline \multirow[t]{3}{*}{ Total } & 3759 & $100 \%$ & 1407 & $100 \%$ & 560 & 659 & $100 \%$ & 2864 \\
\hline & \multicolumn{2}{|c|}{ TV Skopje } & \multicolumn{2}{|c|}{ TV Titograd } & \multicolumn{2}{|c|}{ TV Zagreb } & \multicolumn{2}{|c|}{ SFRY } \\
\hline & $\mathrm{N}$ & $\%$ & $\mathrm{~N}$ & $\%$ & $\mathrm{~N}$ & $\%$ & $\mathrm{~N}$ & $\%$ \\
\hline Children's Program & 0 & $0 \%$ & 420 & $100 \%$ & 0 & $0 \%$ & 1280 & $10 \%$ \\
\hline Documentary & 765 & $41 \%$ & 0 & $0 \%$ & 442 & $32 \%$ & 2594 & $20 \%$ \\
\hline Drama & 363 & $19 \%$ & 0 & $0 \%$ & 839 & $60 \%$ & 4156 & $32 \%$ \\
\hline Educational Program & 90 & $5 \%$ & 0 & $0 \%$ & 56 & $4 \%$ & 2841 & $22 \%$ \\
\hline Entertainment & 0 & $0 \%$ & 0 & $0 \%$ & 30 & $2 \%$ & 224 & $2 \%$ \\
\hline Music & 660 & $35 \%$ & 0 & $0 \%$ & 23 & $2 \%$ & 1842 & $14 \%$ \\
\hline Total & 1878 & $100 \%$ & 420 & $100 \%$ & 1390 & $100 \%$ & 12937 & $100 \%$ \\
\hline
\end{tabular}

Table 3 presents the distribution of programs from each category produced by different Yugoslav republics. Data reveals patterns of the regional specialization within the federation for the specific type of program. Children's programs shared within the JRT network in 1979 came mostly from Slovenia (TV Ljubljana) and Montenegro (TV Titograd). Documentary programs came mostly from Macedonia (TV Skopje), drama from Serbia (TV Belgrade) and Bosnia and Herzegovina (TV Sarajevo). Most of the educational programs shared within JRT came from TV Sarajevo (Bosnia and Herzegovina), entertainment from TV Novi Sad (Vojvodina, Serbia) and music from TV Belgrade (Serbia). Differences between the republics could be traced also within each genre. For example, children's programs shared within JRT that came from TV Ljubljana were mostly fictional, similar to programs from Montenegro, while children's programs from TV Priština consisted of documentaries about the everyday culture of rural youth. Children's program published in the JRT 1979 booklet listed: children fiction, drama (e.g. Ujtata the Wizard, TV Ljubljana), comedy (e.g. Love at Eleven, TV Belgrade), entertainment (e.g. Uncle Brana's Orfeum, TV Belgrade), program showing diversity of everyday culture of children and youth (e.g. The Fisherman Brothers, TV Kosovo), a program devoted to art and culture (e.g. Anka's Drawing, TV Ljubljana). 
Table 3 Percentage of program from each republic in JRT TV Program 1979 (row percentage)

\begin{tabular}{|c|c|c|c|c|c|c|c|c|c|}
\hline & $\begin{array}{c}\text { TV } \\
\text { Belgrade }\end{array}$ & $\begin{array}{c}\text { TV } \\
\text { Ljubljana }\end{array}$ & $\begin{array}{c}\text { TV } \\
\text { Novi Sad }\end{array}$ & $\begin{array}{c}\text { TV } \\
\text { Priština }\end{array}$ & $\begin{array}{c}\text { TV } \\
\text { Sarajevo }\end{array}$ & $\begin{array}{c}\text { TV } \\
\text { Skopje }\end{array}$ & $\begin{array}{c}\text { TV } \\
\text { Titograd }\end{array}$ & $\begin{array}{c}\text { TV } \\
\text { Zagreb }\end{array}$ & $\begin{array}{c}\text { SFRY } \\
(\mathrm{N})\end{array}$ \\
\hline $\begin{array}{l}\text { Children's } \\
\text { program }\end{array}$ & $12 \%$ & $33 \%$ & $6 \%$ & $5 \%$ & $12 \%$ & $0 \%$ & $33 \%$ & $0 \%$ & 1280 \\
\hline Documentary & $14 \%$ & $13 \%$ & $6 \%$ & $9 \%$ & $12 \%$ & $29 \%$ & $0 \%$ & $17 \%$ & 2594 \\
\hline Dram & $27 \%$ & $6 \%$ & $3 \%$ & $8 \%$ & $27 \%$ & $9 \%$ & $0 \%$ & $20 \%$ & 4156 \\
\hline $\begin{array}{l}\text { Educational } \\
\text { program }\end{array}$ & $36 \%$ & $14 \%$ & $2 \%$ & $0 \%$ & $43 \%$ & $3 \%$ & $0 \%$ & $2 \%$ & 2841 \\
\hline Ente & $27 \%$ & $0 \%$ & $46 \%$ & $0 \%$ & $13 \%$ & $0 \%$ & $0 \%$ & $13 \%$ & 224 \\
\hline Mus & $56 \%$ & $0 \%$ & $3 \%$ & $2 \%$ & $2 \%$ & $36 \%$ & $0 \%$ & $1 \%$ & 1842 \\
\hline Total & $29 \%$ & $11 \%$ & $4 \%$ & $5 \%$ & $22 \%$ & $15 \%$ & $3 \%$ & $11 \%$ & 12937 \\
\hline
\end{tabular}

Documentaries from Serbia (TV Belgrade and TV Priština) covered mostly historical themes, documentary programs from TV Zagreb represented everyday culture and personal stories, while TV Sarajevo contributed mostly with documentaries on science and nature. A similar pattern is traceable within the educational genre. The documentary program covered history (e.g. Mexico Under its Sky, TV Belgrade), geography and nature (e.g. From all Meridians, TV Belgrade), world politics (e.g. Battle for Future, TV Ljubljana), art and culture (e.g. The Artist Predrag Pedja Milosavljević, TV Belgrade), sport (e.g. The White Acrobats, TV Ljubljana).

The educational program consisted of historical documentaries (e.g. Emperor Dušan's Code of War, TV Belgrade), everyday culture from an educational perspective targeted to young audiences, like the show Kocka, kocka kockica (Cube, Cube, Cublet, TV Belgrade) or everyday adult culture (e.g. Flowers from Macedonian Homes by TV Skopje, Ski School by TV Ljubljana), health (e.g. Health Care and Hygiene, TV Sarajevo), medicine (e.g. Corneal Transplant, TV Novi Sad), geography (e.g. The Sand Dunes of Delibato, TV Novi Sad), science (e.g. Applied Science and Research, TV Sarajevo), economy and industry (e.g. Fish Breeding in Hatcheries, TV Zagreb), art and culture (e.g. Painters and Sculptors, TV Belgrade), society (e.g. Man and Space, TV Ljubljana). Educational and documentary programs, especially programs aimed at adult audiences, were less oriented toward the legitimization of the socialist way of life than in Imre's (2016) study and more toward educating audiences in art, science, economy, trends in industry and medicine. The documentary program was globally oriented, especially toward South American and Asian countries and members of the Non-aligned movement.

Genres of history (Imre 2016) in Yugoslavia could not be traced exclusively in the historical drama and adventure, but also in documentaries with a focus on art and culture and light entertainment. History was not represented only through important historical political events and actors, but also through the history of art and high culture and urban bourgeois prewar popular culture (light entertainment program). The historical events represented on Yugoslav televisions were from the feudal period in Serbia (e.g. establishment of the Serbian Emperor Dušan), the pre-war and war era (the Albanian and Macedonian fight for autonomy, fight against monarchy, antifascist movement, development of partisan movement, fight against German occupation, development of the communist idea and socialist project), postwar era (problems, obstacles and opposition against implementation of a new revolutionary regime). The post-war era and problems of the implementation of socialist projects were covered in fictional programs (e.g. A Shot in the Plum Orchard Over the River, TV Belgrade) 
with light humour. The program displayed two ways of dealing with these problems: idealism and honesty on the one hand and a bureaucratic and coercive approach on the other. TV Belgrade was most oriented on the past (the pre-war and feudal period), followed by TV Priština (pre-war time) and TV Sarajevo (post-war era), while TV Ljubljana and TV Zagreb were the most present oriented Yugoslav televisions.

Entertainment genres cover mostly mosaic program with music (e.g. Seven Plus Seven, TV Belgrade), folk music and customs (e.g. Hand-Woven Linen and National Costumes of Kupinec, TV Zagreb), light entertainment program with humour (e.g. Our Daily Man series, TV Novi Sad). The entertainment program shared within the JRT network that was produced by TV Belgrade and TV Novi Sad was more light entertainment with popular music compared to entertainment programs from other republics (traditional music and regional customs). The music category covers mostly traditional folk music (TV Priština, TV Sarajevo, and TV Skopje), pop music (TV Novi Sad, TV Skopje), classical music and ballet (TV Belgrade, TV Zagreb) or experimental music (TV Novi Sad). Humour in the analysed entertaining content is not political, but contains elements of comedy of situation or comedy or character. The atmosphere in the entertainment program was nostalgic of the prewar bourgeois popular culture (Our Daily Man, TV Novi Sad with so called "starogradska glazba").

The semi-publicness or openness of television to public critique (Mihelj and Huxtable 2018) could be traced only in one fictional drama Slučaj Filipa Franjića /The Case of Filip Franjić by TV Zagreb (Croatia). The storyline develops around an outspoken worker who is not a member of the communist party and therefore is deprived of a deserved promotion. The drama contains a critique (through humour) of the contradictions of self-management systems. Social problems were more often presented from the personal perspective as individual or personal problems, not as a social critique.

Privatization (Mihelj and Huxtable 2018) defined here as the focus of television on private life, was present on the Yugoslav televisions, though we did not have enough data for more detailed analysis and firm conclusions. Privatization reflects the characteristics of television reception in the private sphere of the home (Scannell 2013, 1995) and shows us that socialist television followed a similar pattern of development as its Western counterparts. Though program from all the republics contained at least some focus on the private perspective, most of such content came from TV Zagreb (Croatia), TV Belgrade (Serbia) and TV Ljubljana (Slovenia).

Within the program category drama, there were comedies (e.g. Cardak ni na nebu ni na zemlji/Tower on Earth and in Heaven, Sumnjivo lice/A Most Suspicious Character, by TV Belgrade), pre-war and war drama (e.g. Gospodin Dimković/Mr. DImković, Osma ofanziva/The Eighth Offensive, TV Belgrade with TV Sarajevo; Knjiga drugova/The Comrades' Book by TV Novi Sad; Đavolje sjeme/Devil's Seed by TV Zagreb), post-war drama (e.g. Pucanj u šljiviku preko reke/A Shot in the Plum Orchard Over the River, TV Belgrade; Tale by TV Sarajevo; Tomo Bakran by TV Zagreb), contemporary drama (e.g. Otac ili samoća/The Father of Loneliness, Večera za Milicu/Dinner for Milica, Zemaljski dani teku/Terrestrial Days Flow Past, by TV Belgrade; Dječak s miševima/The Boy with Mice, Jolanda, tko je to?/Yolanda, Kati Kustecova, and Vida by TV Ljubljana; Junak/The Hero, Ogledalo/The Mirror and Ugriz mraka/The Wound of Darkness, by TV Priština; Izvor/The Source, Nevjeste dolaze/The Brides are Coming, Njen prijatelj FIlip/Her Friend Filip, by TV Sarajevo; Tome and Žene od maletera/Plaster Women by TV Skopje; Punom parom/Full Steam Ahead, Slučaj Filipa Franjića/The Case of Filip Franjić by TV Zagreb), 
historical drama (Epoha pred sudom/An Epoch on Trial by TV Priština; Bijeli zid/The White Wall and Kurir Gočeta/Goceta, the Messenger by TV Skopje) drama based on novels (the Ivo Andrić Serial, Žene na kamenu/Women on the Rock, by TV Sarajevo). Fictional program in Yugoslavia was more important for the legitimization of the socialist way of life and socialist project in general than documentary and educational programs, but with a certain critical and satirical stance. The majority of contemporary drama from 1979 covers personal or existential problems of the main actors (love, loneliness, the urban/rural divide, the clash between modern and conservative forces, professional failure, disappointments, life of expats etc.). Female characters were not as in Imre's (2016) analysis represented as "superheroes" but as nurturing and supportive (Večera za Milicu/Dinner for Milica), demanding (Otac ili samoća/The Father of Loneliness), fatal (Tome, Žene od maltera/Plaster Women), repressed (Izvor/The Source), frustrated or disappointed (Vida, Yolanda).

Gendering as an indicator of tv culture is measured through the number of women listed as authors of the program and present in television content. The number of women listed as authors of the program published in the 1979 JRT booklet was low in all the republics but the lowest in Montenegro (TV Titograd) and Kosovo (TV Priština). The female perspective was the most prominent in the content of TV Ljubljana (Slovenia) and Novi Sad. (Vojvodina, Serbia).

Secularization (Mihelj and Huxtable 2018) describes the more secular than religious orientation of the analysed tv content. Religious content was the most present on TV Belgrade and TV Skopje in fictional and documentary programs.

The analysis of the JRT program booklet with the shared program listed determined that the most transnationally oriented were TV Slovenia and TV Novi Sad, while TV Zagreb (Croatia) was the most oriented toward general Yugoslav themes (Documentary, Educational program).

\section{CONCLUSION}

The article points to the diversities of television cultures under the shared framework of the Socialist Federative Republic of Yugoslavia. Within the shared framework, Slovenia enjoyed the most diverse, the most international and the most commercial tv program of all the Yugoslav republics. Peruško and colleagues (2021) show also that as the most developed republic, Slovenia exhibited more modern and post-modern values, the most advanced alternative culture, a liberalized political and public sphere and the most advanced advertising market in Yugoslavia, followed by Croatia. The television content in Serbia and Montenegro showed a degree of traditionalism in terms of the cultural content and taste which is visible from the fictional program often covering problems related to the modernisation process (urbanisation, clash of rural and patriarchal culture with more liberal, urban culture) and their temporal orientation. A similar tendency is identified in Bosnia and Herzegovina. Serbian televisions (TV Belgrade, TV Priština) and TV Sarajevo (Bosnia and Herzegovina) were the most oriented toward the past. In terms of semi-publicness, privatization, temporal orientation, gendering TV Ljubljana, TV Croatia and TV Novi Sad proved the most developed with the highest presence of female authors and characters, the highest orientation of content to private life and general orientation toward the present. The semi-publicness as a public critique was only 
marginally present in the analysed content, and only on TV Zagreb (Croatia). The results slightly differ from Imre's (2016) comparative analysis of socialist televisions. Here, the reality genres (documentaries, education) were more oriented toward the history of art, history, science, world politics etc. than toward the legitimation of the socialist way of life. Also the female characters were not presented as socialist superheroes but in a more stereotyped manner, as fatal, nurturing, and demanding. The most prominent fictional genre was personal or existential drama where characters face problems such as loneliness, professional failure, disappointments, betrayal, etc. without social critique. A certain nostalgia for pre-war bourgeoisie culture and way of life is present mostly in entertainment programs, especially of TV Novi Sad.

The data here covers only one year of the socialist era (1979) while the analysis of the shared JRT program is based on one document (JRT Television Programme 1979), where we do not have any information about shared news program. Nevertheless, even such a limited focus enables some new insights into the shared Yugoslav media culture, the characteristics of its internally diverse television culture(s) and the specificities of its television culture against other East and South European Socialist countries. The recent book of Zrinjka Peruško and colleagues (2021) shows that not only the socialist but also pre-socialist period shapes current media systems in the region. The more insight we have about historical trajectories of the regional media cultures and their socio-political and historical context, the better our understanding of current trends could be. This is still a work in progress.

\section{REFERENCES}

Eco, Umberto. "A Guide to the NeoTelevision of the 1980s". In Culture and Conflict in Postwar Italy (Essays on Mass and Popular Culture), edited by Z. G. Barański et al., 245-255. UK: Palgrave Macmillan, 1990.

Gumbert, Heather L. Envisioning Socialism. Television and the Cold War in the German Democratic Republic. University of Michigan Press, 2014.

Imre, Anikó. TV Socialism. Durham, London: Duke University Press, 2016.

Imre, A., T. Havens, \& K. Lustyik, eds. Popular Television in Eastern Europe During and Since Socialism, first edition. London: Routledge, 2012.

JRT 79 Television Programmes. Beograd: JRT - Radna grupa za razmenu programa, 1979.

Luthar, Breda and Maruša Pušnik. "Part I: Introduction. The Lure of Utopia: Socialist Everyday Spaces". In Remembering Utopia: The Culture of Everyday Life in Socialist Yugoslavia, edited by Breda Luthar and Maruša Pušnika, 1-36. Washington, DC: New Academia Publishing, 2010.

Kramberger, T., S. Mihelj, \& D. B. Rotar. "Representations of the Nation and of the Other in the Slovenian Periodical Press before and after 1991: Engagements and Implications". In Quality Press in South-eastern Europe, edited by O. Spassov, 276-305. Sofia: Southeast European Media Centre, 2004.

Krippendorff, K. Content Analysis: An Introduction to Methodology, second edition. Thousand Oaks, CA: Sage, 2004.

Mihelj, Sabina and Simon Huxtable. From Media Systems to Media Cultures. Understanding Socialist Television. Cambridge: Cambridge University Press, 2018.

Mihelj, Sabina. "Understanding Socialist Television. Concepts, Objects, Methods". View. Journal of European Television, History \& Culture 3, 5 (2014): 7-16.

Mihelj, Sabina. "The Politics of Privatization: Television Entertainment and the Yugoslav Sixties". In The Socialist Sixties: Crossing Borders in the Second World, edited by A. E. Gorsuch, \& D. P. Koenker, 251267. Bloomington: Indiana University Press, 2013.

Mihelj, S. "Negotiating Cold War Culture at the Crossroads of East and West: Uplifting the Working People, Entertaining the Masses, Cultivating the Nation". Comparative Studies in Society and History 53, 3 (2011): 509-539.

Missika, J.-L. La fin de télévision. Seuil: La République des Idées, 2006.

Meyen, M. \& K. Scwer. "Credibility of Media Offerings in Centrally Controlled Media Systems: A Qualitative Study based on the Example of East Germany". Media, Culture \& Society 29, 2 (2007): 284-303. 
Obradović, S. \& Stupan, A. "Gledaoci o centralnim informativnim dnevnim emisijama”. Novinarstvo 3-4 (1968): 105-110.

Peruško, Zrinjka, Dina Vozab and Antonija Čuvalo. Comparing Post-socialist Media Systems. The Case of Southeast Europe. London and New York: Routledge, 2021.

Peruško, Zrinjka and Antonija Čuvalo. "Comparing Socialist and Post-socialist Television Culture: Fifty Years of Television in Croatia". View. Journal of European Television, History \& Culture 3, 5 (2014): 131-150.

Pušnik, Maruša. "Flirting with Television in Socialism: Proletarian Morality and the Lust for Abundance". In Remembering Utopia: The Culture of Everyday Life in Socialist Yugoslavia, edited by Breda Luthar and Maruša Pušnik, 227-259. Washington, DC: New Academia Publishing, 2010.

Pušnik, M. \& G. Starc. "An Entertaining (R)Evolution: The Rise of Television in Socialist Slovenia". Media, Culture, Society 30, 6 (2008): 777-793

Reifova, I. \& T. Pavličkova. "Invisible Audiences: Structure and Agency in Post-socialist Media Studies". Mediální studia/Media Studies 2 (2013): 130-136.

Ramet, S. P. Balkan Babel: The Disintegration of Yugoslavia from the Death of Tito to the Fall of Milosevic. Boulder: Westview Press, 2002.

Scannell, P. Television and the Meaning of Life: A Phenomenological Approach. Oxford: Blackwell, 2013.

Scannell, P. Radio, Television and Modern Life. Oxford, Cambridge: Blackwell, 1995.

Senjković, R. Izgubljeno u prijenosu: Pop iskustvo soc kulture. Zagreb: Institut za etnologiju i folkloristiku, 2008.

Zubak, M. "Pop-express (1969-1970): Rock-kultura u političkom omladinskom tisku". Časopis za suvremenu povijest 44, 1 (2012): 23-35.

Županov, J. Marginalije o društvenoj krizi. Zagreb: Globus, 1983.

\section{TELEVIZIJSKA KULTURA U SOCIJALISTIČKOJ JUGOSLAVIJI}

Cilj rada je usporediti socijalističke televizijske kulture jugoslavenskih republika. Rad se oslanja na recentna komparativna istraživanja socijalističkih televizija istočne i jugoistočne Europe (Perško et al. 2021, Mihelj and Huxtable 2018; Imre 2016). Polazeći od kategorija koje su razvili Mihelj $i$ Huxtable (2018) i Imre (2016), u radu se jugoslavenske televizije analiziraju s obzirom na: a) žanrovsku raznolikost $i$ udjele različitih vrsta programa, b) stupanj transnacionalizma, c) stupanj spremnosti za otvorenu kritiku društva (publicness), c) fokus na privatni život (privatization), d) rodne obrasce, e) temporalnu orijentaciju, f) karakteristike činjeničnih, humorističnih i povijesnih žanrova. Analiza se temelji na podacima prikupljenim za potrebe nedavno objavljene knjige Peruško, Vozab $i$ Čuvalo (2021) $i$ originalnoj analizi sadržaja publikacije JRT 79 Television programme koji sadrži kratki opis $i$ osnovne podatke o emisijama koje su dio zajedničkog programa unutar JRT mreže. Rezultati otkrivaju razlike među republičkim televizijama (naročito TV Ljubljana, TV Zagreb i TV Novi Sad) u razvoju prema neo-televiziji, kao i razlike u transnacionalnoj, temporalnoj orijentaciji $i$ rodnim obrascima.

Ključne reči: socijalizam, socijalistička televizija, televizijska kultra, Jugoslavija, žanr,

komparativna istraživanja. 